\title{
SUMPING PENANDA KESENIAN ARCA PADA MASA KADIRI - SINGHASARI
}

\section{SUMPING AS AN ART SIGNIFIER OF THE KADIRI-SINGHASARI PERIOD}

\author{
Muhamad Satok Yusuf \\ Mahasiswa Arkeologi, Fakultas IImu Budaya, Universitas Udayana, Jalan Pulau Nias No. 13 Denpasar, Bali, Indonesia; \\ posel: denjatayu2@gmail.com
}

\begin{abstract}
Abstrak. Peradaban masa Hindu-Buddha, berdasarkan tinggalan arkeologinya, merupakan puncak kebudayaan Indonesia. Kerajaan Kadiri dan Kerajaan Singhasari menempati satu ruang kesejajaran sebagai masa-masa puncak kesenian di Jawa Timur, yang ditandai oleh tinggalan arkeologi berupa arca yang dipahatkan secara halus, indah, dan detail. Penggarapan arca mengikuti pakem ikonografi, khususnya pada laksana dan wahana. Walaupun begitu, kebebasan berekspresi si artis dalam penggarapan arca dapat dilihat pada penggambaran perhiasannya, salah satunya adalah sumping. Oleh karena itu, melalui sumping dapat dirunut identitas kesenian pada masa Kadiri-Singhasari, khususnya tipo-morfologi, fungsi, dan makna sumping. Penelitian tentang sumping pada masa Hindu-Buddha sangat jarang dikemukakan secara mendalam. Penelitian ini bersifat kualitatif, tetapi menggunakan analisis kuantitatif dalam bentuk tabulasi dan klasifikasi khusus berdasarkan data yang telah dikumpulkan melalui observasi dan kajian pustaka. Teori mimesis dan kreativitas digunakan untuk mengkaji perkembangan tipo-morfologi sumping pada masa Kadiri-Singhasari. Penggunaan karya sastra sezaman merupakan hal yang penting sebagai pembanding untuk memahami pemaknaan sumping, baik secara profan maupun sakral. Hasil penelitian menunjukkan sumping pada masa Kadiri-Singhasari dibagi menjadi empat tipe, yaitu A, B1, B2, dan C. Tipe B2 dan tipe C merupakan pengembangan yang terjadi pada masa Singhasari. Sumping pada arca menunjukkan fungsinya sebagai hiasan telinga dan media peribadatan. Penggunaan sumping merupakan simbol religio-magis dari pengultusan bunga dalam agama Hindu dan Buddha.
\end{abstract}

Kata kunci: Hindu-Buddha, Kadiri-Singhasari, Ikonografi, Sumping, Teori mimesis, Identitas kesenian, simbol

\begin{abstract}
The Hindu-Buddhist civilization, based on its archaeological remains, is the pinnacle of Indonesian culture. The kingdoms of Kadiri and the Singhasari had simultaneously hit their artistic peak in East Java, which was marked by finely beautiful, sculpted, and detailed statues. Sculpting a statue during the classical period in Indonesia followed Hindu-Buddhist iconography standards, especially regarding 'laksana' (attributes) and 'wahana' (rides). Even so, the artist's freedom of expression in sculpting a statue was depicted by the adornments of the statue, one of which is the sumping. Therefore, through sumping, the identity of the arts with regard to typo-morphology, function, and meaning of sumping, during the Kadiri-Singhasari period can be traced. In-depth research on sumping from the Hindu-Buddhist period has rarely been done. This is qualitative research but uses quantitative analysis in the form of tabulations and special classifications, based on data collected through observation and literature review. The theories of mimesis and creativity were used to study the development of the typomorphology of sumping during the Kadiri-Singhasari period. The use of contemporary literary works was important as a comparison to understand the significance of sumping, whether profane or sacred. The results showed that during the KadiriSinghasari period sumping was divided into four types, i.e. A, B1, B2, and C. Types $B 2$ and $C$ were developments that occurred during the Singhasari period. Sumping showed its function both as ear adornment and a means of worship. The use of sumping is a religious-magical symbol of glorifying flowers in Hinduism and Buddhism.
\end{abstract}

Keywords: Hindu-Buddhist, Kadiri-Singhasari, Iconography, Sumping, Mimesis theory, Art identity, symbol

\section{PENDAHULUAN}

Peradaban masa Hindu-Buddha menjadi puncak kebudayaan di Indonesia berdasarkan banyaknya temuan tinggalan arkeologi yang beragam (Darma 2019). Berbagai tinggalan arkeologi dari masa tersebut berupa arca, bangunan suci, bangunan tempat tinggal, prasasti, gerabah, keramik, dan peralatan logam. Tinggalan tersebut secara fungsi dibagi menjadi dua, yaitu profan dan sakral. Tinggalan arkeologi bersifat profan digunakan sehari-hari untuk berbagai aktivitas manusia, sedangkan tinggalan bersifat sakral hanya digunakan pada masa-masa tertentu untuk tujuan keagamaan. Perbedaan lain dari kedua jenis fungsi tinggalan arkeologi tersebut adalah karakter dan ornamennya. Tinggalan bersifat profan mementingkan kualitasnya daripada 
ornamen yang raya, demikian sebaliknya dengan tinggalan bersifat sakral memiliki banyak ornamen untuk dipersembahkan kepada tokoh pujaannya.

Salah satu tinggalan arkeologi yang vital pada masa Hindu-Buddha adalah arca. Arca menjadi tinggalan arkeologi yang banyak ditemukan dari masa tersebut. Berbagai arca, baik dalam wujud manusia (antropomorfik), hewan (zoomorfik), maupun perpaduan antara manusia dan hewan (teriantrofik) ditemukan di berbagai wilayah di Sumatra, Jawa, Bali, Kalimantan, dan Nusa Tenggara Barat. Pengertian arca dapat ditelusuri melalui sumber India, dalam bahasa Sanskerta disebut bera, vigraha, dan vimbha yang berarti perwujudan dewa. Masyarakat India juga memiliki penyebutan lain untuk arca, sebagai tanu dan rupa yang merupakan gambaran untuk menciptakan rasa Ketuhanan (Maulana 1984).

Bhakta (pemuja), baik dalam agama Hindu maupun Buddha di Indonesia melakukan pemujaan kepada dewata menggunakan media berupa arca. Kehadiran arca merupakan instrumen penting dalam pemujaan pada masa Hindu-Buddha sebab arca menjadi media utama dari aktivitas religi yang berlangsung. Penggambaran arca juga memiliki ketentuan yang berkaitan dengan tata pelaksanaan peribadahan suatu kelompok agama hingga menunjukkan identitas dewa serta agama yang dianut kelompok masyarakatnya. Di sisi lain, arca juga menjadi karya seni dari suatu peradaban. Melalui tinggalan arca, masyarakat masa lalu menelurkan ide dan aktivitasnya ke dalam suatu artefak yang sesuai dengan konsep tiga wujud kebudayaan dalam sudut pandang antropologi (Koentjaraningrat 1984). Walau begitu, penciptaan karya seni pada masa lalu bukan semata-mata sebagai seni murni, melainkan merupakan bentuk dedikasi seniman terhadap suatu keagamaan tertentu (Munandar 1990).

Penggambaran arca pada masa Hindu-Buddha senantiasa terikat pada aturan ikonografi pengarcaan. Penggambaran ikonografi dalam seni arca pada masa Hindu-Buddha tidak sepenuhnya diikuti oleh para seniman pada masa lalu, tetapi juga memiliki beberapa variasi. Variasi tersebut biasanya dipengaruhi oleh berbagai hal, antara lain faktor geografi, perbedaan masa, hingga kelompok keagamaan yang melatarbelakangi pembuatan arca tersebut (Maulana 1997). Beberapa aspek yang tidak bisa diubah dalam pengarcaan adalah laksana (atribut kedewaan) dan wahana (kendaraan dewa). Aspek tersebut merupakan penciri dari sosok dewa tertentu. Hal itu berbeda dengan aspek penggunaan perhiasan pada arca yang tidak seluruhnya mengalami pembakuan. Oleh karena itu terdapat celah kebebasan mengekspresikan kreativitas seniman pada masa itu melalui pemahatan perhiasan yang melekat pada arca.

Salah satu perhiasan khas yang dipakai di telinga arca di Jawa Timur berupa sumping. Perhiasan tersebut seringkali dijumpai pada arca-arca era Kadiri, Singhasari hingga Majapahit. Sumping arca pada masa HinduBuddha masih sangat jarang dibahas secara mendalam. Sampai saat ini kajian mengenai sumping sangat umum, padahal sumping masih dipakai dalam sendratari dan wayang di Jawa dan Bali sebagai busana kaum bangsawan. Kajian tentang sumping telah dilakukan oleh Nanang Dwi Prasidi (1995) dalam skripsinya berjudul "Hiasan Badan pada Arca Batu Masa Singhasari dan Majapahit Koleksi Museum Nasional Jakarta_Kajian Ikonografi". Kajian tersebut terbatas pada arca masa Singhasari dan Majapahit saja. Padahal sumping telah dipergunakan pada arca-arca masa Kadiri.

Pembabakan sejarah pada masa Hindu-Buddha di Jawa Timur memang lazim membagi periode Kadiri dalam masa tersendiri, sedangkan periode Singhasari digabungkan dengan periode Majapahit (Tim Penulisan Sejarah Nasional Indonesia 2008). Gagasan tersebut dapat diterima sebab secara historis antara Kerajaan Singhasari dan Majapahit masih terdapat garis keturunan antarraja. Hal itu berbeda dengan kerajaan Kadiri yang tidak memiliki hubungan darah dengan raja-raja Singhasari ataupun Majapahit, kecuali pernikahan politik yang dilakukan oleh Raja Kërtanāgara dengan Raja Jayakatwang berdasarkan berita dalam prasasti Mula Malurung (1177 Saka). Faktor genealogis tersebut mengindikasikan terjadinya pewarisan kebudayaan dari masa Singhasari ke Majapahit. Menariknya, Edi Sedyawati mengajukan pandangan bahwa Kerajaan Kadiri dan Singhasari menempati periode kesenian yang sama, walaupun secara waktu, hubungan genealogis, dan politik memiliki perbedaan. Hal itu terlihat dari adanya kesamaan langgam arca-arca pada masa Kadiri dan Singhasari, baik secara gaya pahatan maupun ketokohannya (Sedyawati 1985).

Peneliti mengajukan dua rumusan masalah tentang penggunaan sumping pada arca-arca masa KadiriSinghasari berdasarkan pembahasan tentang perhiasan dan kesamaan langgam arca-arca pada masa Kadiri dan Singhasari. Masalah pertama berupa bagaimana bentuk sumping pada masa Kadiri-Singhasari? Masalah kedua adalah bagaimana karya sastra periode Kadiri-Singhasari menggambarkan sumping? 
Penelitian ini berupaya mengkaji perkembangan tipo-morfologi sumping pada masa Kadiri-Singhasari sebagai tipe kesenian yang berbeda dengan masa sebelum maupun sesudahnya. Peneliti juga menggunakan perbandingan sumping pada karya sastra sezaman untuk mengetahui pemaknaan sumping sebagai benda profan maupun sakral. Penelitian ini tidak hanya membahas bentuk dan perkembangan sumping, tetapi juga membahas fungsi, jenis bahan sumping, morfologi motif bunga pada sumping, dan makna sumping, baik sebagai unsur estetika maupun religio-magis. Hal itu disebabkan pembahasan tentang sumping pada masa Hindu-Buddha selama ini masih jarang dikemukakan secara mendalam.

\section{METODE}

Penelitian diawali dengan pengumpulan data menggunakan teknik observasi dan kajian pustaka. Adapun observasi dilakukan, baik secara langsung maupun melalui foto arca-arca dari masa Kadiri dan Singhasari. Arca-arca dari masa tersebut dapat diketahui berdasarkan keletakannya dalam bangunan suci yang telah terkorelasi dengan data prasasti, klasifikasi yang telah dilakukan peneliti terdahulu, dan kesamaan langgamnya. Objek penelitian ini, antara lain: temuan arca dari Situs Gurah, Situs Tondowongso, Situs Adan-adan, Desa Brumbung, Desa Tuliskriyo, Candi Sumbernanas, Candi Kidal, Candi Jago, Kawasan Candi Singosari, Situs Padang Roco, Situs Rambahan, Candi Jawi, Karangkates, dan temuan lepas koleksi Museum Penataran yang memakai hiasan sumping. Langkah selanjutnya adalah pengolahan data berupa pembuatan deskripsi, klasifikasi, dan tabulasi terhadap objek penelitian. Kajian pustaka turut digunakan untuk membantu analisis objek dan bahan penunjang dalam menyelesaikan penelitian ini, terdiri atas artikel ilmiah, skripsi, disertasi, buku, dan sumber pustaka lainnya.

Penelitian ini termasuk dalam penelitian kualitatif yang mengedepankan mutu dan nilai dari suatu kajian dalam bentuk deskriptif daripada numerik. Walau begitu, penelitian ini tetap menggunakan analisis kuantitatif untuk membantu perhitungan dan tabulasi dari objek penelitian. Terlebih lagi, objek yang dikaji dalam penelitian ini berjumlah 50 arca, terdiri atas 16 arca masa Kadiri, 28 arca masa Singhasari, dan enam arca dari periode yang tidak diketahui, tetapi memiliki kesamaan ikonoplastis dengan arca pada masa Kadiri-Singhasari. Analisis kualitatif merupakan proses memahami fenomena di lapangan secara naturalistik dan sirkuler dalam bentuk deskripsi dari berbagai metode ilmiah (Rahmat 2009). Fenomena yang terjadi dalam konteks penelitian ini berupa penggambaran sumping pada arca-arca masa Kadiri-Singhasari.

Peneliti juga menggunakan metode klasifikasi khusus (spesific analysis) untuk mengklasifikasikan tipomorfologi dari 50 arca pada masa Kadiri-Singhasari. Klasifikasi khusus didasarkan pada model klasifikasi analitik yang menggunakan satu atribut sebagai fokus penelitian untuk membentuk modus dari ragam data. Hasil dari klasifikasi analitik berupa mode/standar yang dimiliki dalam suatu budaya (Rouse 1960). Hasil dari metode tersebut berupa tabulasi dan klasifikasi tipe sumping.

Analisis penelitian menggunakan teori mimesis dan kreativitas untuk mengarahkan alur berpikir tentang perkembangan kesenian sumping pada masa Kadiri-Singhasari. Teori mimesis pada dasarnya memberikan pemahaman bahwa manusia menciptakan suatu kreasi berdasarkan persamaan atau kemiripan dengan karya lain (Pasla dan Tinangon 2016). Konsep mimesis biasanya diikuti dengan konsep pemunculan kreativitas, yakni upaya merumuskan kombinasi baru dari berbagai hal secara kreatif dan solid (Haefele 1962).

\section{HASIL DAN PEMBAHASAN}

\section{Perkembangan Seni Arca pada Masa Kadiri-Singhasari}

Masyarakat pada masa lalu membentuk peradaban dan meninggalkan hasil budayanya yang disebut artefak. Artefak yang ditinggalkan mengandung dua hal berupa aktivitas dan gagasan. Oleh sebab itu, melalui kajian artefak dapat direkonstruksi pula aktivitas, gagasan, dan perkembangan budayanya, termasuk dalam hal kesenian. Kesenian merupakan salah satu dari tujuh unsur kebudayaan yang menentukan nilai dan hasil dari peradaban suatu kelompok (Kluckhohn dan Mowrer 1944). Melalui kesenian pula dapat diketahui kreativitas masyarakat berkembang.

Salah satu hasil kesenian yang ikonik adalah arca. Arca merupakan media pemujaan yang digunakan pada masa Hindu-Buddha. John Miksic (Redig 2017) membagi periodisasi arca secara umum menjadi tiga 
masa, yakni masa awal (600 — 900 Masehi), madya (900 —1250 Masehi), dan akhir (1250—1500 Masehi). Arca pada masa awal masih mendapat pengaruh erat dari kebudayaan India, yakni digambarkan dengan badan sedikit gemuk, anggun, dan roman tenang seperti orang bersemadi. Arca pada masa awal digunakan sebagai media pemujaan dewa-dewi Hindu-Buddha. Arca pada masa madya digambarkan berbeda dengan arca pada masa awal, dicirikan dengan tokoh dewa-dewi Hindu-Buddha yang digambarkan kaku, tetapi masih terkesan anggun. Arca pada masa akhir digambarkan kekaku-kakuan seperti mayat.

Masyarakat Jawa pada masa Hindu-Buddha memiliki perbedaan pandangan yang menyebabkan terjadi perkembangan seni arca pada masa awal dengan arca pada masa madya dan akhir. Arca pada masa awal yang mulanya digambarkan dinamis dan naturalistik sesuai panduan pembuatan arca dalam kitab keagamaan, kemudian berubah menjadi arca dengan gaya yang statis dan kaku. Perkembangan gaya pengarcaan tersebut dapat dipahami sebagai bentuk peralihan tren dan penyesuaian budaya yang diterima masyarakat. Jika pada awalnya masyarakat menerima konsepsi pengarcaan dewata yang harus indah dengan penggambaran dinamis, pada kemudian hari masyarakat mengembangkan konsepsi bahwa penggambaran arca tidak harus sesempurna mungkin, tetapi dengan pengadaan simbol-simbol pada arca tersebut sudah mewakili (Maulana 1996). Arca-arca pada masa madya dan akhir juga memiliki konsepsi lain, bukan hanya menggambarkan tokoh dewata seperti arca-arca masa awal, melainkan juga menggambarkan tokoh yang telah meninggal sebagai titisan dewa (Kempers 1959).

Seni arca pada masa Kadiri-Singhasari menempati periodisasi masa madya, menjadi penyambung peradaban antara kesenian masa awal dan kesenian masa akhir. Penggambaran arca-arca dari masa Singhasari sangat indah dan raya. Beberapa arca digambarkan dengan gaya statis, sedangkan arca lainnya digambarkan dinamis dengan konsep demonic berupa hiasan tengkorak dan pita di belakang kepala. Arca-arca pada masa Singhasari menjadi bukti bahwa pada masa tersebut merupakan puncak kesenian masa HinduBuddha di Jawa Timur (Sedyawati 1985; Tim Penulisan Sejarah Nasional Indonesia 2008). Hal itu juga terjadi pada arca-arca masa Kadiri. Arca dari kerajaan Kadiri, antara lain temuan dari Candi Gurah dan Candi Tondowongso, secara ikonoplastis digambarkan serupa dengan arca-arca pada masa Singhasari (Ekawati 2008; Soekmono 1998). Arca digambarkan dinamis dengan pemahatan indah dan halus. Hal yang membedakan arca dari kedua masa tersebut adalah arca pada masa Kadiri digambarkan dengan sandaran polos, sedangkan sandaran pada arca masa Singhasari ditambahkan hiasan lidah api dan vyalaka (hiasan gajah ditunggangi singa dan ditunggangi angsa). Ada pula suatu penciri khusus arca-arca pada masa Singhasari yaitu teratai yang muncul dari bonggolnya. Gaya pengarcaan tersebut menjadi inspirasi seni arca di Majapahit pada kemudian hari, yaitu teratai yang muncul dari jambangan (Bawono dan Zuraidah 2016; Kempers 1959).

\section{Ikonografi pada Busana Arca Kadiri-Singhasari}

Penggambaran arca pada masa Kadiri-Singhasari tidak dapat dilepaskan dari peraturan yang mengikat proses pembuatan dan pakemnya. Arca-arca pada masa tersebut dikelompokkan berdasarkan beberapa kategori, salah satunya adalah ketokohannya. Klasifikasi arca berdasarkan ketokohannya, antara lain berupa arca dewa utama, arca dewa pengiring, arca penjaga, arca manusia, dan arca binatang.

Arca dari masa Kadiri-Singhasari yang termasuk dewa utama antara lain Brahmā, Śiwa, Wișnu, Amoghapāśa Lokeśwara, dan Prajñāpāramitā. Arca dewa pengiring, antara lain Sūrya dan Candra yang termasuk dalam astadikpalaka (delapan dewa penjaga arah angin); Gaṇeśa, Agastya, Durgā Mahisāsuramardhini yang termasuk keluarga Śiwa; dan Hayagrīwa, Sudhanakumāra, Bhṛkuṭī, dan Śyāmatārā yang termasuk murid Amoghapāśa Lokeśwara. Arca penjaga yakni Nandīśwara, Mahākāla, dan Dwārapāla. Arca manusia belum ditemukan hingga saat ini, tetapi beberapa arca dewa termasuk perwujudan dari manusia, antara lain arca Śiwa Mahādewa dari Candi Kidal sebagai perwujudan Anūșapati; arca Amoghapāśa Lokeśwara dari Candi Jago sebagai perwujudan Wișṇuwarddhana; serta arca Śiwa Bhairawa dari kawasan candi Singosari dan arca Joko Dolog (Buddha Mahāksobhya) dari Kandang Gajah yang menjadi perwujudan Kërtanāgara (Kempers 1959; Santiko 2020). Arca tokoh hewan biasanya berkaitan dengan wahana para dewa, berupa dua arca Nandi yang masing-masing ditemukan di Candi Gurah dan Tondowongso (Ekawati 2008).

Ikonografi menjadi ilmu bantu yang penting dalam menganalisis ketokohan suatu arca, khususnya arca dewa. Arca dewata digambarkan, baik sebagai seorang pria, wanita maupun perpaduan keduanya dari agama Hindu atau Buddha. Penggambaran antardewa dalam arca masa Kadiri-Singhasari ataupun masa sebelum dan 
sesudahnya dilengkapi dengan simbol-simbol (ikon) yang menjadi penciri dari tokoh tertentu yang diarcakan. Sebagai contoh, penggambaran Gaṇeśa selalu dicirikan dengan sosok berkepala gajah, rata-rata bertangan empat dengan laksana berupa parasu (kapak), akșamālā (tasbih), modaka (mangkuk), dan danța (gading). la sebagai putra Śiwa juga dilengkapi dengan jațāmakuta (mahkota berbentuk pilinan rambut) dengan hiasan ardacandrakapāla (tengkorak menggigit bulan sabit), dan terdapat trinetra (mata ketiga) di keningnya. Penggambaran tersebut merupakan pakem dari pengarcaan Gaṇeśa dari India hingga nusantara. Walau begitu, terdapat pula unsur-unsur yang tidak wajib hadir dalam pengarcaan tokoh dewa, yakni perhiasan yang dikenakan. Penggambaran perhiasan antartokoh pun bisa bervariasi, tergantung pengaruh keilmuan seniman, makna yang akan disampaikan, geografis, waktu, dan lainnya (Maulana 1997).

Ratnaesih Maulana merinci busana pada arca di Jawa dalam 12 jenis, yaitu: subang/kund, dala (antinganting), hāra (kalung), upawīta (tali kasta), keyura (kelat bahu), kațibhanda (ikat pinggang), sampur, uncal, udarabhanda (ikat dada), kan்kana (gelang tangan), kan்kana (gelang kaki), ikat lutut dan kain (Maulana 1987). Perincian busana tersebut merupakan penggambaran arca-arca di Jawa secara umum, baik pada masa Mataram Kuno maupun Majapahit. Pendapat tersebut kemudian ditambah dan direduksi oleh Nanang Dwi Prasidi, dengan menyesuaikan konteksnya berupa arca-arca pada masa Singhasari dan Majapahit menjadi 15 jenis dengan menghilangkan ikat lutut dan menambahkan makuta (mahkota), jamang, sumping dan cincin kaki. Adapun pendapat Nanang Dwi Prasidi (1995) sesuai dengan penggambaran busana pada arca Prajñāpāramitā (Gambar 1).

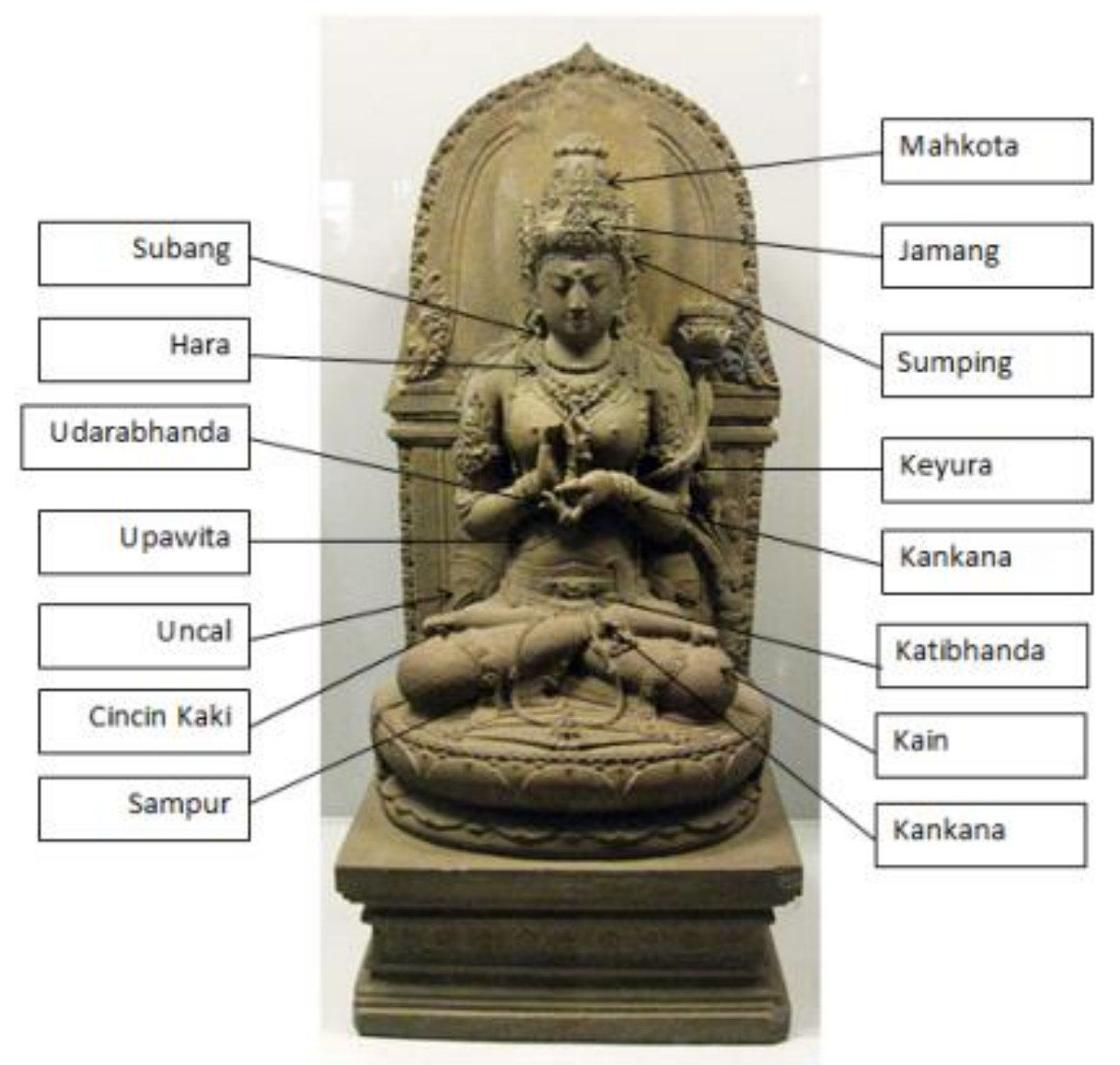

Sumber: Gunawan Kartapranata tahun 2010 dalam m.wikipedia.id; dimodifikasi oleh Yusuf

Gambar 1 Sketsa Ikonografi Arca Prajñāpāramitā berdasarkan Pakem Ikonografi Busana Arca (Prasidi 1995)

Penggambaran rincian busana antara arca Kadiri dan Singhasari tidaklah terlalu banyak perbedaan. Arca-arca dewa dari Kadiri juga digambarkan dengan pakem ikonografi yang lengkap, layaknya penggambaran arca-arca pada masa Singhasari. Perbandingan dilakukan terhadap arca Brahmā dari Candi Tondowongso yang 
termasuk arca pada masa Kadiri dengan arca Brahmā dari kawasan Singosari yang termasuk arca pada masa Singhasari (Gambar 2).

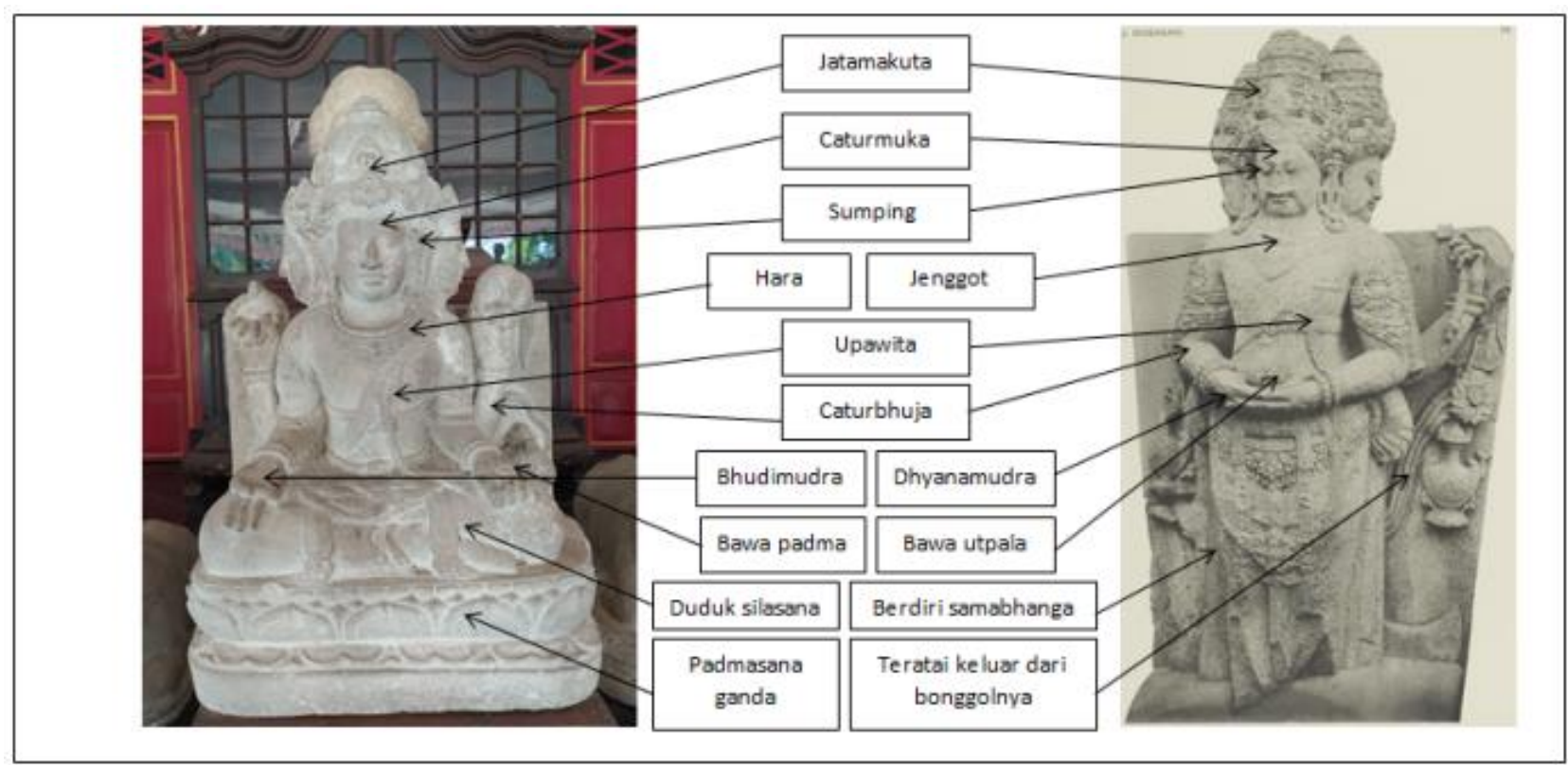

Sumber: KITLV; dimodifikasi oleh Yusuf

Gambar 2 Perbandingan Ikonografi Arca Brahmā dari Candi Tondowongso dengan Arca Brahmā dari Kawasan Candi Singosari

Berdasarkan komparasi kedua arca tersebut hanya kelengkapan arca mulai dari laksana, raut muka, sikap tubuh, hingga busana yang terpenuhi. Perbedaan di antara keduanya hanya terletak pada sikap duduk arca, mudrā dua tangan bawah, bentuk mahkota, dan hiasan teratai. Arca Brahmā Singhasari digambarkan berdiri dengan dua tangan bawah membentuk dyanamudrā (kedua tangan ditengadahkan dengan tangan kanan menumpang di atas tangan kiri) yang terdapat utpala (kuncup bunga teratai) di atasnya, memakai jațāmakuta, dan teratai keluar dari bonggolnya di sisi kiri arca. Arca Brahmā Kadiri digambarkan duduk silāsana dengan sikap tangan kanan bawah membawa padma (bunga teratai merah yang telah mekar), tangan kiri bawah melakukan bhudimudrā (tangan menengadah dengan ibu jari dan telunjuk disatukan), dan memakai jațāmakuta. Adapun kesamaan busana dan ikonoplastis kedua arca tersebut digambarkan oleh sikap samabhanga (simetris antara tubuh bagian kiri dan kanan), tetapi masih memperlihatkan bentuk pahatan yang halus, dinamis, dan sesuai dengan ukuran arca (talamana). Busana yang dikenakan arca tersebut sesuai dengan perincian yang ditentukan oleh Prasidi (1995), yakni sebanyak 15 jenis, termasuk penggunaan sumping pada kedua objek tersebut. Berdasarkan perbandingan kedua arca tersebut, maka dapat diterima pendapat dari Edi Sedyawati (1985) tentang kesamaan langgam antara arca Kadiri dan Singhasari.

\section{Sumping pada Arca Kadiri-Singhasari}

Sumping menjadi salah satu ornamen penting dalam tata busana pengarcaan pada masa KadiriSinghasari. Sumping adalah bunga, daun, atau lainnya yang digunakan di telinga, tetapi juga dapat dimaknai sebagai perhiasan telinga yang dibentuk bunga (Zoetmulder dan Robson 1994). Sumping berbeda dengan kunḑala dan subang. Sumping pada arca masa Kadiri-Singhasari berupa bunga yang disematkan di atas daun telinga. Adapun kunḑala dan subang merupakan anting-anting yang diletakkan pada bagian bawah daun telinga yang dilubangi. Baik arca pria maupun wanita juga dihias dengan sumping dan kunḑala atau subang.

Sejarah kemunculan sumping hingga saat ini belum dapat ditelusuri lebih jauh. Kemungkinan besar sumping merupakan kesenian asli nusantara sebab dalam ikonografi India tidak dikenal perhiasan sumping. Sumping juga ditemukan pada arca Śiwa dan pahatan relief di Candi Prambanan, tetapi hanya beberapa tokoh saja yang ada sematan sumping. Penggambaran sumping juga didapati pada arca-arca yang berasal dari Petirtan Jolotundo (Ardanarīswara) dan Belahan (Airlangga dan dua arca wanita). Penggambaran sumping 
kemudian menjadi tren kesenian pada arca masa Kadiri, Singhasari hingga Majapahit. Adapun penggambaran sumping pada arca masa Kadiri dan Singhasari memiliki kesamaan morfologi bila dibandingkan dengan sumping pada arca masa Majapahit. Sumping pada masa Kadiri-Singhasari digambarkan dengan bentuk ceplok bunga dan kelopak bunga berdasarkan hasil tabulasi dari 50 arca (Tabel 1). Hal itu berbeda dengan sumping pada masa Majapahit yang terdiri atas untaian daun mengelilingi bagian atas hingga belakang telinga seperti huruf "S" (Gambar 3).

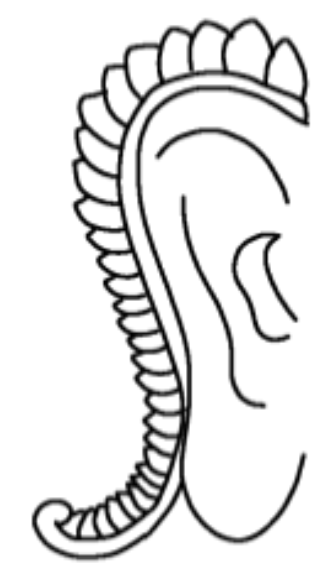

Sumber: Digambar oleh Yusuf tahun 2021

Gambar 3 Sketsa Sumping Tipe Untaian Daun Langgam Majapahit

Sumping digambarkan pada arca pria dan wanita, baik bernafaskan Hindu maupun Buddha. Antara arca pria dan wanita tidak terdapat perbedaan bentuk sumping yang dikenakan. Begitu pula dengan arca bernafaskan Hindu dan Buddha. Arca pada masa Kadiri yang digambarkan dengan sumping berbentuk ceplok bunga, antara lain fragmen kepala Boddhisatwa Situs Adan-adan, Dwārapāla Situs Adan-adan, dan Agastya dari Candi Sumbernanas. Arca pada masa Singhasari yang digambarkan dengan sumping berbentuk ceplok bunga, antara lain Śiwa Mahādewa dari Candi Kidal; Mamaki dari Candi Jago; Śiwa Bhairawa, Brahmā, dan sepasang arca Dwārapāla dari Kawasan Candi Singosari, serta Prajñāpāramitā dari Candi Putri. Menariknya sumping juga menjadi penghias arca Gaṇeśa dari Boro-Tuliskriyo, dua arca Gaṇeśa dari Kawasan Candi Singosari, Gaṇeśa dari Karangkates serta sebuah Gaṇeśa yang kini disimpan di Museum Penataran. Penggambaran sumping pada arca Gaṇeśa juga diselipkan pada bagian atas daun telinga gajah, layaknya penggunaan sumping pada arca-arca berbentuk manusia.

Sumping pada arca-arca masa Kadiri-Singhasari digambarkan dalam dua jenis, yakni sumping bertipe ceplok bunga dan tipe kelopak bunga. Sumping bertipe ceplok bunga (sumping tipe A) berupa kuntum bunga mekar yang terdiri atas 4, 5, dan 8 kelopak bunga dengan lingkaran besar di bagian tengah (Gambar 4). Sumping tersebut memiliki ukuran lebih kecil dibandingkan dengan sumping tipe kelopak bunga. Sumping tipe kedua berupa kelopak bunga, yaitu bunga yang hanya terdiri atas beberapa kelopak (tidak utuh seperti ceplok bunga). Sumping tipe kelopak bunga rupanya terdiri atas dua jenis, yakni kelopak bunga dengan ujung lancip (sumping tipe B) dan kelopak bunga dengan ujung lingkaran (sumping tipe C). Sumping tipe kelopak bunga ujung lancip diklasifikasikan lagi menjadi dua jenis, yakni kelopak bunga saling tumpang tindih (sumping tipe B1) dan kelopak bunga sejajar (sumping tipe B2) (Gambar 5 dan 6), sedangkan sumping tipe kelopak bunga ujung lingkaran hanya satu jenis (Gambar 7). Perbedaan selanjutnya dari sumping tipe $B$ dan tipe $C$ adalah jumlah kelopaknya. Sumping tipe B memiliki kelopak antara 4, 5, 6, 7, 8, dan 12 buah, sedangkan sumping tipe C memiliki kelopak antara 4, 5, 6, dan 8 buah. Klasifikasi dari berbagai jenis sumping tersebut digambarkan pada gambar 8 . 


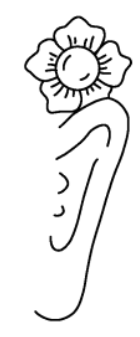

Sumber: Digambar oleh Yusuf tahun 2021

Gambar 4 Sketsa Sumping Tipe A (Ceplok Bunga)

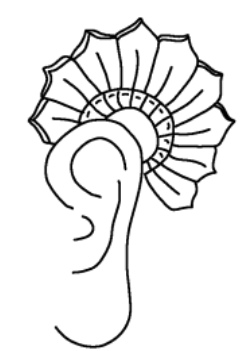

Sumber: Digambar oleh Yusuf tahun 2021

Gambar 6 Sketsa Sumping Tipe B2 (Kelopak Bunga Ujung Lancip Berjajar)

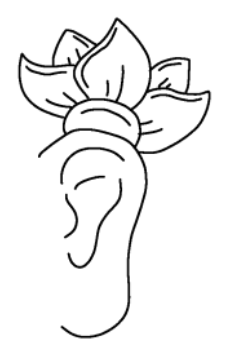

Sumber: Digambar oleh Yusuf tahun 2021

Gambar 5 Sketsa Sumping Tipe B1 (Kelopak Bunga Ujung Lancip Tumpang Tindih)

Sumber: Digambar oleh Yusuf tahun 2021

Gambar 7 Sketsa Sumping Tipe C (Kelopak Bunga Ujung Lingkaran)

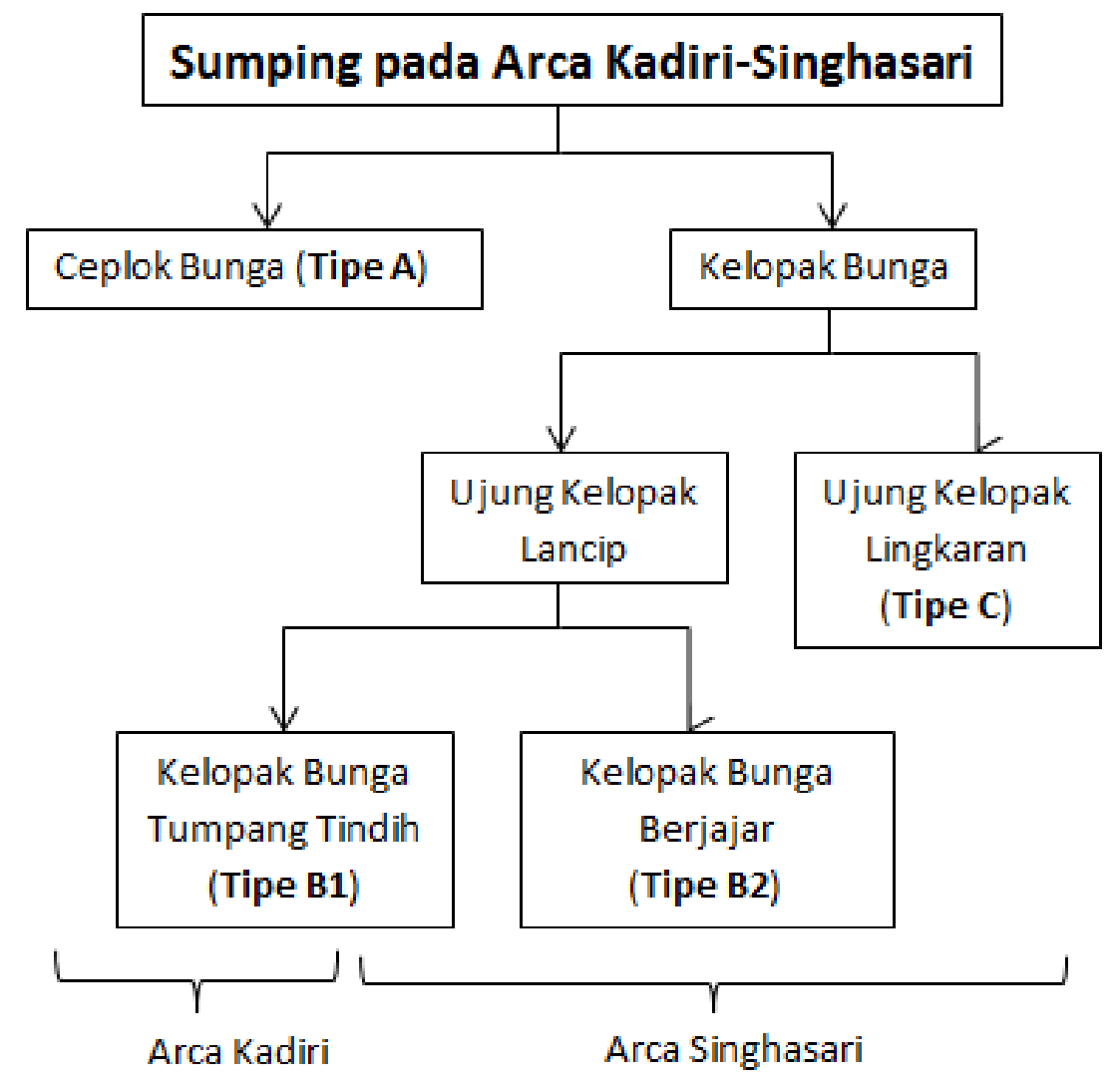

Sumber: Disusun oleh Yusuf tahun 2021

Gambar 8 Bagan klasifikasi tipe sumping pada Arca Kadiri-Singhasari

Sumping yang sering digunakan pada arca-arca masa Kadiri-Singhasari adalah tipe B. Sumping tersebut menjadi modus dengan jumlah $54 \%$ berdasarkan tabulasi dari 50 arca masa Kadiri-Singasari. Sumping tipe $A$ digunakan arca sebanyak $26 \%$ dan sumping tipe C sejumlah 20\%. Menariknya, arca pada masa Singhasari 22 
digambarkan memiliki jenis sumping lebih bervariasi daripada arca pada masa Kadiri. Arca pada masa Singhasari digambarkan dengan sumping tipe A, B1, B2, dan C, sedangkan arca-arca pada masa Kadiri digambarkan dengan sumping tipe A dan B1. Morfologi sumping memiliki perkembangan pada masa Singhasari. Walaupun beberapa sumping arca pada masa Singhasari digambarkan sama dengan sumping arca pada masa Kadiri, terdapat variasi tipe sumping baru yang dimunculkan, yakni tipe B2 dan C.

Perkembangan tipo-morfologi sumping arca pada masa Kadiri-Singhasari dapat ditelaah melalui sudut pandang mimesis dan kreativitas. Para seniman Kadiri yang menciptakan karya seni berupa arca merupakan bentuk mimesis dari lingkungannya, dapat berupa: pelatihan keterampilan; pengetahuan dari gurunya; seleksi dan revisi dari karya sebelumnya; hingga tiruan arca yang telah ada. Hal itu sesuai dengan uraian dari Soekmono yang menyatakan bahwa bangunan suci pada masa Kadiri merupakan tipe peralihan dari langgam bangunan tipe Jawa Tengahan dengan Tipe Jawa Timuran. Bangunan dan arca pada masa Kadiri menunjukkan ciri-ciri kesenian Mataram Kuno, tetapi gaya pemahatan atributnya menunjukkan tipe baru (Soekmono 1998). Hal itu juga terjadi dengan kesenian pada masa Singhasari.

Seniman pada masa Singhasari tampaknya juga melakukan mimesis terhadap kesenian pada masa Kadiri. Arca dengan sumping tipe A dan B1 merupakan salah satu bentuk dari proses mimesis yang terjadi. Hal itu dapat dipahami sebab pada hakikatnya sebagian wilayah Singhasari merupakan hasil dari penaklukan Kerajaan Kadiri pada tahun 1222 (Riana 2009; Tim Penulisan Sejarah Nasional Indonesia 2008). Sebelum penaklukan itu terjadi, Nāgarakrtāgama dan Pararaton memberitakan para Brahmāna Kadiri melarikan diri ke Tumapel (nama lama Singhasari) untuk meminta perlindungan Ken Angrok (Riana 2009). Peristiwa tersebut dapat menjadi indikasi adanya migrasi para pejabat kerajaan dari Kadiri ke Singhasari, termasuk para seniman kerajaan. Peran Brahmāna dan seniman sangat vital dalam menghasilkan kesenian Kerajaan Kadiri dan Singhasari. Brahmāna merupakan tokoh penting dalam penetapan aturan, waktu pembuatan beserta konsepsi arca seperti yang dianjurkan kitab-kitab keagamaan. Para seniman berperan dalam mengeksekusi ide dari Brahmāna dan raja dalam wujud kesenian (arca) yang dihasilkan.

Terdapat dua jenis ketentuan yang perlu diperhatikan seniman dalam membuat arca. Ketentuan pertama bersifat wajib berupa kelengkapan atribut tokoh dewa, wahana, ukuran hingga bentuk arca harus sempurna. Arca sebagai perwujudan dari dewa merupakan objek sakral yang harus digambarkan sempurna. Oleh karena itu, pengerjaannya ditentukan dalam kitab-kitab keagamaan seperti Silpaśāstra, Suprabhedāgama, Karanāgama dan Pāñcaratna Vaikhānasāgama (Darma 2019). Adapun ketentuan kedua bersifat bebas menyesuaikan kreativitas sang seniman. Ketentuan ini biasanya berkaitan dengan di luar atribut wajib dari tokoh seperti bentuk śirascakra, bentuk prabha, jumlah gelang, jumlah kalung, hiasan pita, motif batik hingga keberadaan tanaman teratai dan sumping. Kebebasan itulah yang kemudian melahirkan kreativitas seniman, seperti yang diungkapkan oleh Haefele sebagai upaya merumuskan kombinasi baru dari berbagai hal secara kreatif dan solid (Haefele 1962).

Sumping yang telah ada pada masa Kadiri berjumlah dua tipe (tipe A dan B1) kemudian dikreasikan para seniman Singhasari berkembang menjadi empat tipe (tipe A, B1, B2, dan C). Proses kreativitas tersebut bebas dilakukan seniman mengingat sumping tidak didapati, baik dalam aturan seni arca maupun ikonografi arca di India. Para seniman Singhasari sengaja menciptakan inovasi bentuk sumping berdasarkan proses mimesis yang telah dilakukan pada sumping masa Kadiri. Tipe sumping B2 dan C lahir pada masa Kërtanāgara, berupa arca-arca Buddha dari Candi Jago dan arca dari Kawasan Candi Singosari. Hal itu dapat dipahami sebab masa Kĕrtanāgara merupakan masa paling damai di Singhasari. Sang raja mewarisi takhta dengan jalan damai dari ayahnya, Wișnuwarddhana. Bahkan, sang raja juga mampu meluaskan pengaruhnya dengan ekspedisi Pamalayu dan usaha menantang Kubhilai Khan (Santiko 2020) Para seniman dapat mengerjakan karya seni dengan fokus dan indah ketika berada di kondisi damai. Oleh karena itu, pada masa Kërtanāgara karya seni Singhasari mengalami puncaknya dan mengilhami kesenian pada masa Majapahit.

\section{Sumping dalam Karya Sastra}

Arca menjadi salah satu bukti dari adanya aktivitas manusia pada masa lalu. Melalui arca dapat dirunut gambaran kehidupan masa lalu, setidaknya tentang penggunaan busana. Busana yang dikenakan arca menjadi representasi dari busana yang dikenakan masyarakat pada masa lalu, termasuk penggunaan sumping. Sumping telah digunakan masyarakat pada masa Kadiri-Singhasari berdasarkan beberapa sumber kesusatraan 
yang sezaman. Karya sastra pada masa Kadiri yang membahas sumping, antara lain Sumanasāntaka karya Empu Monaguna, Bhāratayuddha karya Empu Sedah dan Empu Panuluh pada era pemerintahan Jayabhaya serta Bhomāntaka.

Kesusastraan pertama, yakni Sumanasāntaka yang digubah oleh Empu Monaguna pada era pemerintahan Kertajaya (1112 -1138 Saka) dari Kadiri. Empu Monaguna menghadiahkan karya tersebut kepada guru syairnya, Sri Warsajaya (Zoetmulder 1985). Sang rakawi menuliskan Putri Indumati dan Pangeran Aja menggunakan sumping. Penggunaan sumping bunga pada Putri Indumati ditemukan pada pupuh 10 bait ke-19 berbunyi:

"mingkil tapwan agöng payodhāra nirānglëwihi bungah i tuntung ing gading; hyang hing tāman angiṇ̣arat sĕmu ni rūpa nira n ahayu munggu ring taman; tistis lālana tan hanāngiringakĕn laku nira kadi tan tuhantuhan; molah sumping irāsanālum awĕnĕs bangun awědu ri luñcip ing mata" (Worsley dkk. 2014).

Artinya "Payudaranya (Putri Indumati) yang membengkak tidaklah besar, tetapi melebihi pentil gemilang buah kelapa; ketika duduk di taman, kecantikannya serupa jelmaan dewi taman; dia habiskan waktu luang sendirian tanpa teman seakan-akan dia bukan seorang putri; kala bunga asana di telinganya bergerak, maka layu dan pucatlah bunga itu, seolah takut kepada sudut tajam matanya".

Adapun Pangeran Aja digambarkan memakai sumping setelah mandi di Sungai Narmadā sebagaimana tertulis dalam pupuh 30 bait ke-12.

"mĕntas pwa yāngadĕg angunggul i tīra ning Iwah; ganggĕng lawan sarasijanghibĕki ry awaknya; mëttāwěrö něhĕr asumping aganţa kambang' abhrā katinghalan ikā kadi nāgapușpa" (Worsley dkk. 2014).

Artinya, "Dia (Pangeran Aja) keluar dari air dan berdiri menjulang di tepi sungai; rumput ganggěng dan pohon padma menyelubungi sekujur tubuhnya; terangsang dan bingung, ia mengenakan hiasan telinga dan lonceng bunga; dia tampak segemerlap pohon nāgapușpa".

Putri Indumati menyematkan bunga asana (Terminalia tomentosa) sebagai sumping. Bunga asana tampaknya tidak dikenal di Indonesia saat ini, mungkin penyebutan bunga tersebut antara di India berbeda jenis dengan spesies di Indonesia. Hal itu berbeda dengan Pangeran Aja yang mengenakan perhiasan sumping yang mungkin terbuat dari bahan logam, bukan berasal dari bunga seperti yang dikenakan Putri Indumati. Berdasarkan berita kakawin tersebut didapatkan informasi bahwa sumping pada masa Kadiri dibagi menjadi dua jenis berdasarkan bahannya, yakni sumping yang terbuat dari logam dan bunga yang difungsikan sebagai sumping.

Sumping tipe ceplok bunga (tipe A) memiliki morfologi serupa dengan kelopak bunga dewandaru (Mesua ferrea). Bunga dewandaru pada masa Hindu-Buddha dikenal sebagai nāgasari atau nāgapușpa (Zoetmulder dan Robson 1994). Bunga nāgasari merupakan bunga yang indah, sering ditanam di sekitar bangunan suci. Saking indahnya, Empu Monaguna mengibaratkan keindahan busana Pangeran Aja saat keluar dari sungai Narmadā layaknya pohon nāgasari.

Bentuk morfologi sumping tipe B1 dan B2 menyerupai kelopak bunga teratai merah (Nymphaea sp). Tanaman tersebut lazim digunakan sebagai simbol kesucian dalam agama, baik Hindu maupun Buddha. Teratai atau padma memiliki fungsi sebagai āsana (tempat duduk/alas), pengapit arca masa Singhasari hingga Majapahit, dan sumping penghias telinga. Selain itu, bunga teratai juga dipahatkan sebagai hiasan percandian di Jawa Timur, khususnya pada masa Majapahit (Bawono dan Zuraidah 2016; Wurjantoro 2018). Teratai juga menjadi bunga yang disajikan dalam upacara masyarakat Hindu hingga saat ini (Sukrawati 2019). Mengenai bentuk kelopak bunga teratai pada sumping tipe B1 dan B2 dapat dibandingkan dengan kelopak bunga teratai yang keluar dari bonggolnya pada arca-arca dari Candi Jago (Gambar 9). Antara kelopak bunga teratai pengapit arca Sudhanakumāra dan kelopak sumping pada masa Kadiri-Singhasari memiliki kesamaan morfologi. 


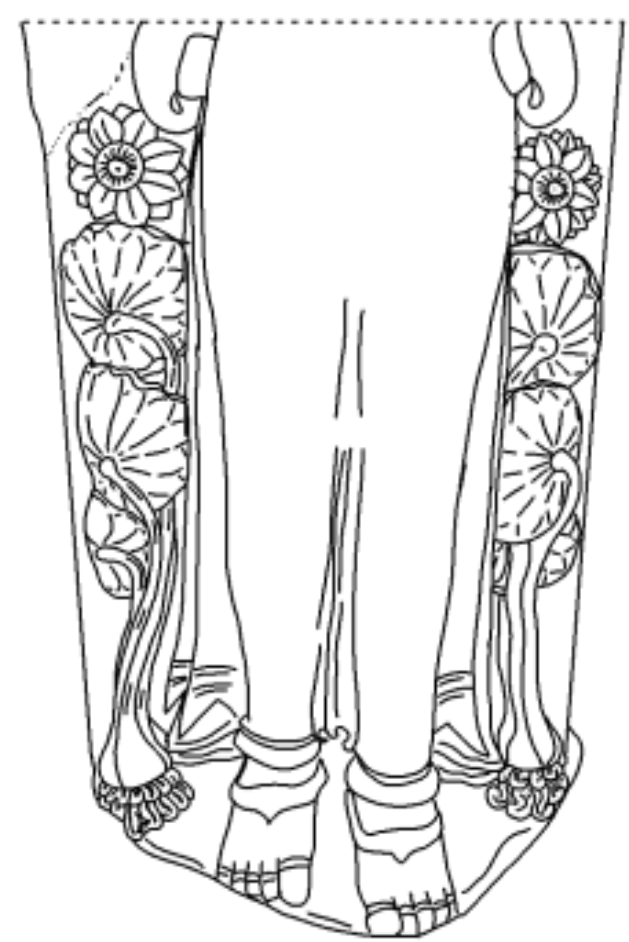

Sumber: Digambar oleh Yusuf tahun 2021

Gambar 9 Sketsa Teratai Keluar dari Bonggol pada Arca Sudhanakumāra Candi Jago

\section{Fungsi dan Makna Sumping}

Sumping memiliki fungsi sebagai penghias tubuh, baik pria maupun wanita. Karya sastra Kakawin Sumanasāntaka secara tidak langsung juga menggambarkan fungsi dari sumping, baik sebagai penghias tubuh moleknya Putri Indumati maupun atribut kebesaran Pangeran Aja. Selain itu, sumping juga memiliki fungsi lain yang lebih sakral daripada fungsi profan sebagai unsur estetika saja. Kakawin Bhāratayuddha pupuh 4 bait ke2 dan 3 menceritakan keberadaan bunga srigading dan asana sebagai media ritual pemujaan Ganeśa. Kedua bunga tersebut kemudian dicuri oleh para wanita sebagai jimat asmara (Sedyawati 1985).

Kakawin Sumanasāntaka memberitakan bahwa rangkaian bunga sumanasa merupakan bunga surgawi, yang menjadi penghias alat musik Dewa Narada, jatuh ke pangkuan Indumati dan Aja. Seketika kedua pasangan tersebut pingsan dan mengakhiri kehidupan Indumati yang lepas dari kutukan Brahmin Trnawindu bahwa ia akan mencapai ajalnya ketika dijatuhi bunga sumanasa. Bunga juga memiliki fungsi magis seperti dalam kakawin Bhomāntaka yang menceritakan bahwa Tilottamā membawa sesajen bunga untuk menghormati abu Yajñawati (Zoetmulder 1985). Bahkan, konsep sesajen bunga sebagai penghormatan sosok yang telah meninggal juga dikenal pada masa Majapahit, disebut sebagai puspa lingga (Riana 2009). Selanjutnya, bunga juga memiliki kesaktian menghidupkan kembali orang yang telah meninggal asalkan memiliki bunga wijayamālā. Berita tersebut didapat dari kakawin Bhomāntaka yang menceritakan kesaktian bunga wijayamālā pemberian Dewi Bhumi, ibunda Bhoma (Zoetmulder 1985).

Penggunaan sumping dalam bentuk bunga asli masih dilakukan masyarakat Bali saat beribadah. Masyarakat Bali menyelipkan bunga sesaji (canang sari) sebagai simbol berakhirnya upacara pemujaan, kemudian dilanjutkan dengan menerima tirta (air suci) dan biji (beras). Adapun alasan penyematan bunga tersebut memiliki makna religio-magis sebagai manifestasi Tuhan, bentuk kebaktian bhakta serta agar dihindarkan dari segala halang-rintang (Sukrawati 2019; Surata, Gata, dan Sudiana 2015).

Adapun secara makna, bunga merupakan unsur sakral dalam agama Hindu dan Buddha. Bunga teratai merah menjadi landasan duduk (asana) dari dewa, dinamakan padma. Bunga teratai kuncup (utpala) menjadi simbol dari arwah yang telah meninggal, biasanya digambarkan pada arca perwujudan pada masa Singhasari dan Majapahit (Ayatrohaédi 1981; Jaya 2015). Bunga teratai juga menjadi penciri kesenian Singhasari dan Majapahit. Bunga teratai menjadi simbol dari sebuah kesucian karena dianggap sebagai kecantikan yang tetap hadir walau lahir dari tanah berlumpur. 
Penggunaan bunga dewandaru menjadi sumping pada masa Kadiri-Singhasari merupakan bentuk pemanfaatan potensi alam sekitar. Bunga tersebut pada masa Majapahit digambarkan menghiasi berbagai bangunan candi, karesian hingga Ibukota Majapahit (Riana 2009). Makna magis dari bunga dewandaru dapat dilihat pada masa selanjutnya. Bunga dewandaru dalam pandangan masyarakat Jawa dianggap sebagai bunga keramat yang mampu menangkal santet, mendatangkan berkah, keselamatan, dan kesejahteraan. Biasanya bunga tersebut tumbuh liar, ditanam di tempat tertentu, baik makam orang berpengaruh maupun di depan rumah tokoh tertentu (Yuliah, Hakim, dan Hadiyan 2018). Masyarakat Jawa menyebut kembar mayang (rangkaian janur dan bunga dalam upacara pernikahan di Jawa) sebagai Kalpataru Dewandaru, simbol dari kebahagiaan dan keselamatan (Panjaitan dan Manugeren 2019). Masyarakat Bali juga menggunakan bunga dewandaru sebagai sesajen saat upacara ngaben dan pitra yadnya (Surata dkk. 2015; Yuliah dkk. 2018).

Penggunaan bunga pada sumping dapat disejajarkan, baik dengan makna kesakralan maupun magis dari bunga tersebut. Bunga pada sumping menjadi sarana permohonan doa kepada Tuhan terkait asmara seperti tergambar dalam Kakawin Bhāratayuddha. Bunga dapat pula dimaknai sebagai magi, baik dalam kakawin Sumanasāntaka maupun Bhomāntaka yang memiliki sifat paradoksal, sebagai pembunuh tetapi juga menjadi penghidup dari kematian. Bahkan, anggapan magis dari bunga masih berlanjut hingga masa kini seperti penggunaan bunga dewandaru pada pernikahan masyarakat Jawa, upacara ngaben masyarakat Bali, dan penanaman pohon di makam orang berpengaruh serta rumah sebagai pembawa berkah dan penghindar santet.

\section{PENUTUP}

Perkembangan karya seni senantiasa berjalan seiring perkembangan zaman dan pengetahuan. Karya seni juga memiliki identitas tersendiri menyesuaikan faktor ideologi, geografi hingga politik. Sumping merupakan salah satu karya seni dari masa Kadiri-Singhasari yang memiliki identitas khas periode tersebut. Morfologi sumping pada masa Kadiri-Singhasari terdiri atas sumping tipe A, tipe B1, tipe B2, dan tipe C. Sumping digambarkan pada arca pria dan wanita, baik bernafaskan Hindu maupun Buddha tanpa ada perbedaan morfologi. Morfologi awal sumping adalah tipe A dan B1 yang dijumpai pada sebagian besar arca pada masa Kadiri-Singhasari. Morfologi sumping mengalami perkembangan pada masa Singasari dengan adanya penambahan sumping tipe B2 dan $\mathrm{C}$ yang lahir pada era pemerintahan Kërtanāgara. Sumping juga digunakan pada arca Gaṇeśa dari kedua kerajaan tersebut walau secara morfologi telinga arca tersebut berupa telinga gajah. Sumping berbentuk ceplok bunga kemungkinan meniru morfologi bunga dewandaru, sedangkan sumping berbentuk kelopak bunga dengan ujung lancip serupa dengan padma yang tumbuh dari bonggolnya pada arcaarca dari Candi Jago.

Sumping dijumpai pada karya sastra pada masa Kadiri, antara lain dalam kakawin Sumanasāntaka, Bhomāntaka, dan Bhāratayuddha. Sumping memiliki dua fungsi baik secara profan maupun sakral. Fungsi sumping secara profan sebagai penghias telinga, baik pria maupun wanita, berupa bunga asli ataupun dari logam. Fungsi sakral dari sumping sebagai ajimat dan media peribadatan yang memiliki fungsi religio-magis. Konsep kesakralan sumping dapat ditelusuri berdasarkan konsep kesakralan bunga dalam peradaban HinduBuddha di Indonesia dan ritual yang dilakukan masyarakat Jawa dan Bali hingga saat ini.

Penelitian tentang sumping masih belum tuntas. Sejarah kemunculan sumping hingga saat ini belum dibahas, termasuk asal-muasal budaya penggunaan atribut tersebut. Atribut hiasan telinga tersebut juga memiliki variasi morfologi yang lebih beragam pada masa kemudian, bahkan penggunaannya juga menyebar ke Jawa, Bali, dan Thailand. Oleh karena itu, perlu adanya penelitian lanjutan untuk mengungkap eksistensi sumping. 


\section{DAFTAR PUSTAKA}

Ayatrohaédi. 1981. "Kamus Istilah Arkeologi I." Jakarta: Proyek Penelitian Bahasa dan Sastra Indonesia dan Daerah.

Bawono, Rochtri Agung, dan Zuraidah. 2016. "Ragam Seni Hias Majapahit: Penciri Hasil Budaya Majapahit." Seminar Nasional Seri Bahasa Sastra dan Budaya, 1-6.

Darma, I. Kadek Sudana Wira. 2019. "Pengarcaan Dewa Wisnu pada Masa Hindu-Buddha di Bali - Abad VIIXIV Masehi." Forum Arkeologi 32(1):51-62. doi: http://dx.doi.org/10.24832/fa.v32i1.548.

Ekawati, Lisa. 2008. "Arca-arca dari Candi Tondowongso dan Candi Gurah, Kediri." Berkala Arkeologi 28(2):3651. doi: $10.30883 / j b a . v 28 i 2.362$.

Haefele, John W. 1962. "Creativity and Innovation." London: Reinhold Publishing Corporation.

Jaya, Ida Bagus Sapta. 2015. "Kesejajaran Konsepsi Arca Perwujudan di Kamboja Asia Tenggara." Pustaka Jurnal IImu-ilmu Budaya, 15(1):39-51.

Kempers, A. J. Bernet. 1959. "Ancient Indonesian Art." Massachusetts: Hardvard University Press.

Kluckhohn, Clyde, dan O. H. Mowrer. 1944. "Culture and Personality: a Conceptual Scheme." American Anthropologist 46(1):1-29. doi: 10.1525/aa.1944.46.1.02a00020.

Koentjaraningrat. 1984. "Kebudayaan Mentalitas dan Pembangunan." Jakarta: PT. Gramedia.

Maulana, Ratnaesih. 1984. "Ikonografi Hindu." Jakarta: Fakultas Sastra Universitas Indonesia.

Maulana, Ratnaesih. 1987. "Hiasan Arca pada Masa Hindu-Buddha di Jawa." dalam Diskusi IImiah Arkeologi II Estetika dalam Arkeologi Indonesia. Jakarta: Pusat Penelitian Arkeologi Nasional.

Maulana, Ratnaesih. 1996. "Perkembangan Seni Arca di Indonesia." Laporan Penelitian. Depok: Universitas Indonesia.

Maulana, Ratnaesih. 1997. "Gambaran Umum Ikonografi Siwa di India dan Sumber-sumber Tertulis." Laporan Penelitian. Jakarta: Universitas Indonesia.

Munandar, Agus Aris. 1990. "Kegiatan Keagamaan di Pawitra: Gunung Suci di Jawa Timur Abad 14-15 M." Tesis. Depok: Universitas Indonesia.

Panjaitan, Indra Purnawan, dan M. Manugeren. 2019. "Symbolic Meanings of Kembar Mayang in Javanese Wedding Ceremony at Desa Medan Sinembar Kecamatan Tanjung Morawa Kabupaten Deli Serdang." Journal of Language 1(1):1-10. doi: https://doi.org/10.30743/jol.v1i1.1123.

Pasla, Vincent D., dan Alvin J. Tinangon. 2016. "Arsitektur Mimesis." Media Matrasain 13(1):47-55.

Prasidi, Nanang Dwi. 1995. "Hiasan Badan pada Arca Batu Masa Singhasari dan Majapahit Koleksi Museum Nasional Jakarta - Kajian Ikonografi." Skripsi. Depok: Universitas Indonesia.

Rahmat, Pupu Saeful. 2009. "Penelitian Kualitatif." Equilibrium 5(9):1-8.

Redig, I. Wayan. 2017. "Pengarcaan Pratima Dewa-Dewa Hindu di Bali: Kesinambungan Tradisi Pengarcaan Jaman Indonesia Hindu." Prosiding Seminar Nasional Sastra dan Budaya II, 278-85.

Riana, I. Ketut. 2009. "Kakawin Dēśa Warnnana uthawi Nāgara Krtagama - Masa Keemasan Majapahit." Jakarta: PT. Kompas Media Nusantara.

Rouse, Irving. 1960. "Society for American Archaeology." American Antiquity 25(3): 313-23. doi: 10.1017/s0002731600093963.

Santiko, Hariani. 2020. "Kehidupan Beragama Raja Kertanagara." Kalpataru Majalah Arkeologi 29(1): 29-38. doi: https://doi.org/10.24832/kpt.v29i1.634.

Sedyawati, E. 1985. "Pengarcaan Ganeśa Masa Kadiri dan Sinhasāri: Sebuah Tinjauan Kesenian." Disertasi. Jakarta: Universitas Indonesia.

Soekmono, R. 1998. "Gurah, The Link between the Central and the East-Javanese Arts." Hal. 1-20 dalam Bulletin of the Archaeological Institute of the Republic of Indonesia No 6. Jakarta: Jajasan Purbakala.

Sukrawati, Ni Made. 2019. "Acara Agama Hindu." diedit oleh I. W. Wahyudi. Denpasar: UNHI Press.

Surata, I. Ketut, I. Wayan Gata, dan I. Made Sudiana. 2015. "Studi Etnobotanik Tanaman Upacara Hindu Bali sebagai Upaya Pelestarian Kearifan Lokal." Jurnal Kajian Bali 5(2):265-84.

Tim Penulisan Sejarah Nasional Indonesia. 2008. "Sejarah Nasional Indonesia II - Zaman Kuno." diedit oleh M. D. Poesponegoro dan N. Notosusanto. Jakarta: Balai Pustaka.

Worsley, Peter, S. Soepomo, Margaret Fletcher, dan Thomas Hunter. 2014. "Kakawin Sumanasantaka: Mati Karena Bunga Sumanasa." Jakarta: Yayasan Pustaka Obor Indonesia. 
Wurjantoro, Edhie. 2018. "Anugerah Sri Maharaja-Kumpulan Alihaksara dan Alihbahasa Prasasti-Prasasti Jawa Kuna dari Abad VIII_XI." Depok: Depatermen Arkeologi Fakultas IImu Pengetahuan Budaya Universitas Indonesia.

Yuliah, Lukman Hakim, dan Yayan Hadiyan. 2018. "Nagasari (Mesua ferrea): Budidaya dan Potensinya sebagai Tanaman Obat." Proceeding Biology Education Conference 25(1):808-12.

Zoetmulder, P. J. 1985. "Kalangwan Sastra Jawa Kuno Selayang Pandang." Jakarta: Djambatan.

Zoetmulder, P. J., dan S. O. Robson. 1994. "Kamus Jawa Kuna Indonesia." Jakarta: PT. Gramedia Pustaka Jaya. 
Tabel 1 Penggunaan Sumping pada Arca Kadiri-Singhasari

LAMPIRAN

\begin{tabular}{|c|c|c|c|c|c|c|c|c|}
\hline \multirow[b]{2}{*}{ NO } & \multirow[b]{2}{*}{ ARCA } & \multicolumn{2}{|r|}{ LOKASI } & \multirow[b]{2}{*}{ PERIODE } & \multicolumn{2}{|c|}{ JENIS SUMPING } & \multirow{2}{*}{$\begin{array}{l}\text { JUMLAH } \\
\text { KELOPAK }\end{array}$} & \multirow[b]{2}{*}{ UJUNG KELOPAK } \\
\hline & & ASAL & SEKARANG & & $\begin{array}{l}\text { CEPLOK } \\
\text { BUNGA }\end{array}$ & $\begin{array}{c}\text { KELOPAK } \\
\text { BUNGA }\end{array}$ & & \\
\hline 1 & Brahmā & Situs Gurah & Museum Nasional Jakarta & Kadiri & & $\mathrm{V}$ & 5 & Lancip \\
\hline 2 & Candra & Situs Gurah & Museum Nasional Jakarta & Kadiri & & $\mathrm{V}$ & 5 & Lancip \\
\hline 3 & Sūrya & Situs Gurah & Museum Nasional Jakarta & Kadiri & & $\mathrm{V}$ & 5 & Lancip \\
\hline 4 & Brahmā & Situs Tondowongso & BPCB Provinsi Jawa Timur & Kadiri & & $\mathrm{V}$ & 5 & Lancip \\
\hline 5 & Nandīśwara & Situs Tondowongso & BPCB Provinsi Jawa Timur & Kadiri & & $\mathrm{V}$ & 4 & Lancip \\
\hline 6 & Candra & Situs Tondowongso & BPCB Provinsi Jawa Timur & Kadiri & & $\mathrm{V}$ & 5 & Lancip \\
\hline 7 & Candra & Situs Tondowongso & BPCB Provinsi Jawa Timur & Kadiri & & $\mathrm{V}$ & 5 & Lancip \\
\hline 8 & Sūrya & Situs Tondowongso & BPCB Provinsi Jawa Timur & Kadiri & & $\mathrm{V}$ & 5 & Lancip \\
\hline 9 & Boddhisatwa & Situs Adan-adan & Museum Bagawanta Bhari & Kadiri & V & & & Lingkaran \\
\hline 10 & Dwārapāla & Situs Adan-adan & Situs Adan-adan & Kadiri & V & & & Lingkaran \\
\hline 11 & Śiwa Caturmuka & Desa Brumbung & Balai Desa Brumbung & Kadiri & & $\mathrm{V}$ & 12 & Lancip \\
\hline 12 & Gaṇeśa & Boro Tuliskriyo & Boro Tuliskriyo & Kadiri & & $\mathrm{V}$ & 4 & Lancip \\
\hline 13 & Brahmā & Candi Sumbernanas & Museum Penataran & Kadiri & & $\mathrm{V}$ & 12 & Lancip \\
\hline 14 & Agastya & Candi Sumbernanas & Museum Penataran & Kadiri & V & & 5 & Lingkaran \\
\hline 15 & Śiwa Gajasura & Candi Sumbernanas & Museum Penataran & Kadiri & & $\mathrm{V}$ & 5 & Lancip \\
\hline 16 & Mahākāla & Candi Sumbernanas & Museum Penataran & Kadiri & & $\mathrm{V}$ & 5 & Lingkaran \\
\hline 17 & Śiwa Mahadewa & Candi Kidal & Royal Tropical Institute & Singhasari & V & & 1.. (aus) & Lingkaran \\
\hline 18 & Relief Garudeya & Candi Kidal & Candi Kidal & Singhasari & & $\mathrm{V}$ & 5 & Lingkaran \\
\hline 19 & Amoghapāśa & Padang Roco & Museum Nasional Jakarta & Singhasari & & $\mathrm{V}$ & $12 \& 5$ & Lancip \\
\hline 20 & Bhairawa Buddha & Rambahan & Museum Nasional Jakarta & Tidak diketahui & & $\mathrm{V}$ & 7 & Lancip \\
\hline 21 & Sudhanakumāra & Candi Jago & Museum Nasional Jakarta & Singhasari & & V & 8 & Lancip \\
\hline 22 & Bhṛuțī & Candi Jago & Museum Nasional Jakarta & Singhasari & & $\mathrm{V}$ & 8 & Lingkaran \\
\hline 23 & Hayagrīwa & Candi Jago & Museum Nasional Jakarta & Singhasari & & $\mathrm{V}$ & 6 & Lingkaran \\
\hline 24 & Śyāmatārā & Candi Jago & Museum Nasional Jakarta & Singhasari & & $\mathrm{V}$ & 8 & Lancip \\
\hline 25 & Manjusri & Candi Jago & Tidak diketahui & Singhasari & & $\mathrm{V}$ & 5 & Lancip \\
\hline 26 & Mamaki & Candi Jago & Museum Nasional Jakarta & Singhasari & $\mathrm{V}$ & & 5 & Lingkaran \\
\hline 27 & $\begin{array}{l}\text { Durgā } \\
\text { Mahisāsuramardhini }\end{array}$ & Candi Singosari & Museum Leiden & Singhasari & & V & 12 & Lancip \\
\hline 28 & Mahākāla & Candi Singosari & Museum Leiden & Singhasari & & $\mathrm{V}$ & 4 & Lancip \\
\hline
\end{tabular}


Sumping Penanda Kesenian Arca pada Masa Kadiri - Singhasari - Muhamad Satok Yusuf (15-30) Doi: 10.24832/nw.v15.i1.456

\begin{tabular}{|c|c|c|c|c|c|c|c|c|}
\hline \multirow[b]{2}{*}{ NO } & \multirow[b]{2}{*}{ ARCA } & \multicolumn{2}{|r|}{ LOKASI } & \multirow[b]{2}{*}{ PERIODE } & \multicolumn{2}{|c|}{ JENIS SUMPING } & \multirow[b]{2}{*}{$\begin{array}{l}\text { JUMLAH } \\
\text { KELOPAK }\end{array}$} & \multirow[b]{2}{*}{ UJUNG KELOPAK } \\
\hline & & ASAL & SEKARANG & & $\begin{array}{c}\text { CEPLOK } \\
\text { BUNGA }\end{array}$ & $\begin{array}{c}\text { KELOPAK } \\
\text { BUNGA }\end{array}$ & & \\
\hline 29 & Nandīśwara & Candi Singosari & Museum Leiden & Singhasari & & V & 7 & Lancip \\
\hline 30 & Gaṇeśa & Candi Singosari & Museum Leiden & Singhasari & & V & 6 & Lancip \\
\hline 31 & Bhairawa Kalacakra & Candi Singosari & Museum Leiden & Singhasari & V & & 8 & Lancip \\
\hline 32 & Agastya & Candi Singosari & Candi Singosari & Singhasari & & V & 6 & Lancip \\
\hline 33 & Gaṇeśa & Gunung Semeru & Museum Leiden & Singhasari & & V & 6 & Lancip \\
\hline 34 & Prajñāāāramitā & Candi Putri & Museum Nasional Jakarta & Singhasari & V & & 8 & Lingkaran \\
\hline 35 & Ganeśa & Kawasan Singosari & Museum Nasional Bangkok & Singhasari & & V & 6 & Lancip \\
\hline 36 & Brahmā & Kawasan Singosari & Museum Volkenkunde & Singhasari & & V & 8 & Lancip \\
\hline 37 & Brahmā & Kawasan Singosari & Museum Mpu Purwa & Singhasari & V & & & Lingkaran \\
\hline 38 & Dwārapāla & Kawasan Singosari & Kawasan Singosari & Singhasari & V & & 4 & Lingkaran \\
\hline 39 & Dwārapāla & Kawasan Singosari & Kawasan Singosari & Singhasari & V & & 4 & Lingkaran \\
\hline 40 & Trnawindu & Kawasan Singosari & Terbakar & Singhasari & & V & 6 & Lingkaran \\
\hline 41 & $\begin{array}{l}\text { Durgā } \\
\text { Mahisāsuramardhini }\end{array}$ & Candi Jawi & Museum Tantular & Singhasari & & V & 7 & Lancip \\
\hline 42 & Nandīśwara & Candi Jawi & $\begin{array}{l}\text { Pengelolaan Informasi } \\
\text { Majapahit }\end{array}$ & Singhasari & & V & 12 & Lancip \\
\hline 43 & Camundi & Ardimulyo & $\begin{array}{l}\text { Pengelolaan Informasi } \\
\text { Majapahit }\end{array}$ & Singhasari & & V & 2.. (aus) & Lancip \\
\hline 44 & Gaṇeśa & Karangkates & Karangkates & Singhasari & & V & 6 & Lingkaran \\
\hline 45 & Wișṇu & Tidak diketahui & Museum Airlangga & Tidak diketahui & & V & 4 & Lingkaran \\
\hline 46 & Relief Arjunawiwaha & Kekunoan Mleri & $\begin{array}{l}\text { Pengelolaan Informasi } \\
\text { Majapahit }\end{array}$ & Tidak diketahui & & V & 6 & Lancip \\
\hline 47 & Wișṇu & Blitar & Museum Penataran & Tidak diketahui & & V & 8 & Lancip \\
\hline 48 & Laksmi & Blitar & Museum Penataran & Tidak diketahui & & V & 8 & Lancip \\
\hline 49 & Gaṇeśa & Blitar & Museum Penataran & Tidak diketahui & & V & 5 & Lancip \\
\hline 50 & Sūrya & Blitar & Museum Penataran & Tidak diketahui & & V & 4 & Lingkaran \\
\hline
\end{tabular}

Sumber: Ditabulasikan oleh Yusuf tahun 2021 